\title{
圈 \\ Client Intimacy \& \\ Performance Advice: Determinants of Trust in the Public Accountant - SME Client Relationship
}

Michael Cherry ${ }^{1}$, Dianne McGrath ${ }^{2}$ and Chris Baumann ${ }^{3}$

\begin{abstract}
This multi-discipline research investigated the determinants of trust in the relationship between Australia's public accountants and their small and medium-sized (SME) clients. In excess of four hundred SME owners, across Australia, were surveyed to test a proposed model and client intimacy variables were found to be the most significant predictors of trust in this important relationship. Offer-related variables, primarily the provision of advisory or performance-related services (rather than conformance-related services), were also found to be significant, however, at a lesser level than client intimacy and relationship variables. The multi-dimensionality of the trust construct was also highlighted.
\end{abstract}

JEL Classification: M49, D91.

Keywords: Trust, trust multi-dimensionality, public accountant, SME, conformance services, performance services, client intimacy, advisory services.

\footnotetext{
${ }^{1}$ Charles Sturt University, Sydney, Australia

${ }^{2}$ Charles Sturt University, Albury, Australia

${ }^{3}$ Macquarie University, Sydney, Australia \& Seoul National University (SNU), Seoul, Korea
} 


\section{Introduction \& Prior Research:}

This study sought to identify the determinants, or antecedents, of trust in the Australian public accountant - SME client relationship, by utilising a multi-discipline approach, drawing from prior client relationship and public accounting literature. It tested the conceptual model previously developed and presented by one of authors (Cherry, 2016). A review of prior work, particularly the studies by Saunders, Wu, Li, and Weisfeld (2004) and Blackburn, Carey, and Tanewski $(2010,2014)$ identified that the area of trust remains under-researched for business to business relationships generally and for Australian public accountant - SME client relationships specifically. This paper empirically tested the conceptual model (refer Figure 1 below), trust definition and the role of the public accountant developed by Cherry (2016). In doing so, it explored the oft-quoted adage of the public accountant as the SME clients' trusted partner (Bennett \& Robson, 2005; Berry, Sweeting, \& Goto, 2006; Cherry, 2016; Jay \& Schaper, 2003; Kirby \& King, 1997; Leung, Raar, \& Tangey, 2008), to better understand the value provided to their client base. This is the first academic study to attempt to identify and quantify the determinants of trust in this relationship. The work of Dyer and Chu (2011) and Blackburn et al. $(2010,2014)$ provided the theoretical framework for this research, as summarised in Cherry (2016). The Dyer and Chu (2011) paper investigated the determinants of trust within the broader business to business buyer-seller relationship (relating to supplier-automaker relationships in the US, Japan \& Korea). Additionally, the Blackburn et al. (2010, 2014) papers were utilised, as they represents the most comprehensive paper addressing the topic of trust, anecdotally, from the specific perspective of the Australian public accountant - SME client relationship.

Australia's public practice accountancy sector is estimated to comprise in excess of 30,000 firms, with annual revenue in the vicinity of $\$ 20$ billion (Windle, 2017). Industry concentration is low with the 'Big Four' (Deloitte Touche Tohmatsu/Deloitte, KPMG, Ernst \& Young/EY and PricewaterhouseCoopers) representing just under $23 \%$ of the overall marketplace (Windle, 2017). 'Second Tier' providers (approximately 50 firms) represent a further estimated $15 \%$ of the market (Khadem, 2012). The balance of the sector (Third Tier and Beyond) therefore numbers around 30,000 practices and accounts for approximately $60 \%$ ( $\$ 12$ billion pa) of the overall market. These practices would indicate that they primarily service Australia's small to medium enterprises (SMEs), high net worth individuals and tradespersons. This paper explored the relationship between these Third Tier and Beyond accountancy practices and their SME client base.

The Association of Chartered Certified Accountants, ACCA (2016), highlights major drivers for change within the global accountancy profession through to 2025. They also highlight the technical, ethical and interpersonal skills and competencies required to adapt to such changes. The first of these drivers is increased regulation and governance, which is predicted to have the strongest impact on the profession. Secondly, the spread of digital technologies is forecast to transform accounting and the competencies required by public accountants. The third driver relates to changing client expectations, requiring public accountants to, "... meet more requests for comprehensive and forward-looking information and more frequent ad hoc reporting from ever more stakeholders" (ACCA, 2016, p. 10). They suggest, "All professional accountants will be expected to look beyond the numbers. They will need to collaborate and partner with people outside the business; interpret and explain the numbers; provide insight and information; help 
organisations to achieve short-term goals and longer-term objectives; think and behave more strategically and become more involved in decision-making than before" (ACCA, 2016, p. 10). Globalisation is said to provide opportunities and challenges relating to differences in business practices and at the same time harmonisation of accounting and business standards. These change drivers are expected to impact technical and interpersonal skills across; audit and assurance; corporate reporting; financial management; tax, governance risk and ethics; and notably, strategic planning and performance management. Within Australia, Windle (2017) highlights the following trends impacting public accounting services; technological change, integration within the broader Asia-Pacific region, global regulatory requirements and continued industry consolidation and continued growth in high-value advisory services across the coming five years. The persistence in forecasts of the increasing need for strategic planning, performance management and advisory services is a highlight of the above works and speaks very specifically to public accountants as potential and potent SME business advisors.

\section{Trust Definition}

The review by Cherry (2016) of trust definitions and trust models in the business and professional service context identified the importance of the following trust elements within the Australian public accountant - SME client relationship:

1. Confidence (Dyer \& Chu, 2011)

2. Acceptance of vulnerability (Blois, 1999; Dyer \& Chu, 2011)

3. Person and offer-related variables (Coulter \& Coulter, 2002)

4. Conformance and performance advice (or compliance and non-compliance advice) (Berry et al., 2006)

A trust definition was developed by Cherry (2016) from the above to describe trust within the Australian public accountant - SME client relationship. It draws from prior work describing general trust definitions, business trust and ultimately, trust in the Australian public accountant SME client relationship. This definition speaks to the major elements of broader trust (Blois, 1999), B2B trust (Coulter \& Coulter, 2002; J. H. Dyer \& Chu, 2011) and professional services trust globally (Berry et al., 2006) as well as within Australia (Blackburn et al., 2010, 2014). Consistent with the work by Dowell, Morrison, and Heffernan (2015), it also acknowledges trust as a multi-dimensional construct, with both client intimacy and offer-related characteristics, identified as affective and cognitive elements by these authors. In doing so, the definition developed provides a sound basis for further investigation of the conceptual model to describe the determinants of trust within the Australian public accountant - SME client relationship. This study used the following definition of trust as it relates to this relationship:

"The SME client's confidence that the public accountant will act proactively in their interests and not exploit their vulnerabilities." (Cherry, 2016, p. 15) 


\section{The Role of the Public Accountant}

The role of the public accountant (Berry et a1., 2006; CAANZ, 2013; CPAAustralia, 2017; IPA, 2017) was also explored and shown to include two broad components:

1. Conformance advice component - statutory/compliance matters such as taxation

2. Performance advice component - non-compliance consulting activities relating to business improvement and growth

Further recent trends within the accountancy sector, outsourcing and offshoring in particular (Noroozi \& Addison, 2008) present opportunities for an increase in the provision of performance related advice by public accountants (Kirby \& King, 1997). The literature acknowledges public accountants as the most prevalent advisors to SMEs, but this in itself does not ne cessarily equate to the trusted advisor (Bennett \& Robson, 2005; Berry et al., 2006; DEWRSB, 1996; Jay \& Schaper, 2003; Kirby \& King, 1997; Leung et al., 2008). The distinction between prevalent and trusted advisor is important and, according to Blackburn et al. (2010) there exists an expectation gap between accountants and their clients and that this gap relates to whether the accountant provides broader business advice. That is, according to Blackburn et al. (2010), the provision of such additional services is a requirement for an accountant to be viewed, "as a business expert, a 'trusted partner', and a confidante who has empathy and provides a personal relationship to the owner-manager" (Blackburn et al., 2010, p. $1)$.

Few studies provide firm empirical guidance on trust determinants within the Australian public accountant - SME client space (Blackburn et al., 2010, 2014). Th e literature reviewed also confirms that the advice provided is primarily of a statutory or compliance nature (Berry et al., 2006; Kirby \& King, 1997), with public accountants generally not considered for broadbased management issues. This is at odds with the conformance/performance components detailed in the previous paragraphs. There was acceptance of the benefit of advisory work to overall SME performance (Berry et al., 2006; Dyer \& Ross, 2007). This further supports the opportunity for public accountants to explore broadening of their service offerings to include both conformance and performance components. This conformance versus performance question was further highlighted in the expectations gap identified by several authors (Kirby \& King, 1997; Leung et al., 2008). These papers have identified issues relating to accountants' attitudes towards raising awareness of SME clients to business issues and perceptions by SMEs of the improvement role which accountants can play, as well as differing views on key economic issues and trends. The distinction between conformance and performance service offerings by public accountants was also brought to light in this review.

Most importantly, the Blackburn et al. $(2010 ; 2014)$ paper identified the provision of performance advice (or non-compliance business advisory services) as a potentially important determinant of trust, to address the identified expectations gap, within the public accountant - SME client relationship. Blackburn et al. $(2010 ; 2014)$ suggest the following potential trust determinants; that 
trust is built via an on-going relationship, principally through the provision of conformance or compliance services, that it is built up over time through social rapport. The importance of empathy is also highlighted as vital to the success of the relationship and the provision of performance (or non-compliance) business advisory services (Blackburn et al., 2010; 2014).

There are a number of accounting related associations in Australia, with the Institute of Public Accountants, CPA Australia and Chartered Accountants Australia and New Zealand as the three legally recognised local professional accounting bodies (Australian Accountants Directory, 2017). The role of the public accountant was distilled from a review of the objectives of these recognised accreditation bodies (IPA, CPA \& CAANZ), and identifies both conformance-related and performance-related activities, as follows:

"Australia's public accountants provide clients with financial conformance and performance services. Financial conformance services speak to compliance-related activities, whereas financial performance services speak to broader business advisory activities, aimed at business improvement and growth." (Cherry, 2016, p. 6)

\section{Research Question:}

This study explored the relationship between Australia's SMEs and their public accountants. It sought to better understand the value provided by these accounting services providers to their SME client base. It also questioned the oft-quoted notion of the public accountant as the SMEs' most trusted advisor (Bennett \& Robson, 2005; Berry et al., 2006; Jay \& Schaper, 2003; Kirby \& King, 1997; Leung et al., 2008). Is this assertion or adage correct? Can it be justified? What does it actually mean and what are the antecedents or determinants of this trust? The work by (Cherry, 2016, p. 8), highlights, "the foundation need for trusted advisor status amongst public accountants. Across international boundaries we see the concept of trust and the value associated with the profession." The primary objective of the study was to unpack the above and answer the very specific question:

\section{What are the determinants, or antecedents, of trust in the public accountant-SME client relationship?}

As a result of the findings from prior research in this area, and as summarised by Cherry (2016), a set of hypotheses and proposed conceptual model were developed in an attempt to describe the antecedents of trust in the public accountant - SME client relationship.

\section{Hypotheses:}

The following hypotheses have been proposed for the investigation of the determinants of trust in the SME - public accountant relationship (Cherry, 2016). These have been developed after review of prior scholarly papers and particularly the Dyer and Chu (2011) and Blackburn et al. (2010, 2014) papers highlighted above. The independent variables chosen relate to the person/relationship-related and offer-related characteristics detailed by many of the models detailed in the literature review (Cherry, 2016). The Blackburn et al. $(2010,2014)$ papers, which 
specifically address trust within the Australian public accountant - SME client arena, proposes the role of trust, relationships and professional ethics in the provision of business advice, beyond traditional statutory/compliance matters. Their primary focus relate to client intimacy elements of the relationship (person/relationship-related variables), but also speaks to offer-related variables.

The Dyer \& Chu (2011) paper, which investigated the issue of trust within the broader B2B environment across supplier-automaker relationships in the US, Japan and Korea, and found that trust is significantly correlated with activities which promote relationship continuity. In this paper, "the process-based perspective" or offer-related variables contributed most strongly as trust determinants across each country in the study (Dyer \& Chu, 2011, p. 259). Dyer and Chu (2011, p. 259) also found "embeddedness" (person/relationship-related, or client intimacy variables) to be important in Japan. Although there is not a strong consistency in findings across these relevant studies, they do provide some common themes in the area of relationship strength. The distillation of the findings of the above papers has resulted in the following hypotheses as possible antecedents, or determinants, of trust within the Australian public - SME client relationship space. Consistent with previous broader findings, the independent variables are separated into person/relationship-related (client intimacy) and offer-related characteristics.

\section{Client Intimacy (Relationship or Person-Related) Characteristics}

Hypothesis $1\left(\mathbf{H}_{\mathbf{1}}\right)$ - The longer the duration of the commercial relationship, the higher the SME's trust in the public accountant, per Dyer \& Chu (2011); Gooderham et al. (2004). (LENGTH)

Hypothesis $2 \mathbf{( \mathbf { H } _ { 2 } )}$ - Consistent with the work by Blackburn et al. $(2010 ; 2014)$ and (Dyer \& $\mathrm{Chu}, 2011)$, it is proposed that the greater the face-to-face interaction between the public accountant and the SME, the higher the SME's trust in the public accountant. (FACE)

Hypothesis $3\left(\mathbf{H}_{3}\right)$ - The broader the engagement (beyond the normal commercial client/professional services organisation engagement) between the public practice firm and the SME, the higher the SME's trust in their public accountant (Blackburn et al., 2010, 2014; Kirby \& King, 1997). (ENGAGEMENT).

\section{Offer-Related Characteristics}

Hypothesis $4 \mathbf{( \mathbf { H } _ { 4 } )}$ - The greater the assistance provided by the public accountant, the higher the SME's trust in the public accountant (Blackburn et al., 2010, 2014; Gooderham et al., 2004). This speaks to the breadth of compliance/conformance-related offerings provided by the public accountant to their SME client. (ASSISTANCE)

Hypothesis $\mathbf{5}\left(\mathbf{H}_{5}\right)$ - The more non-compliance related assistance provided by the public accountant, the higher the SME's trust in the public accountant (Blackburn et al., 2010, 2014; Kirby \& King, 1997). This business advice moves beyond the core compliance/conformancerelated offerings. (ADVISORY) 
Hypothesis $6\left(\mathbf{H}_{\mathbf{6}}\right)$ - The public accountant's accreditation body, Institute of Public Accountants (IPA), CPA Australia (CPA) or Chartered Accountants Australia and New Zealand (CAANZ) impacts the level of trust in their public accountant (Blackburn et al., 2010, 2014).

(ACCREDITATION)

Hypothesis $7\left(\mathbf{H}_{7}\right)$ - The larger the public practice firm, the higher the SME's trust in their public accountant (Dyer \& Chu, 2011). (SIZE)

\section{Model for Empirical Testing}

Drawing on the Dyer \& Chu (2011) and Blackburn et al. $(2010,2014)$ studies and identified variables, the following conceptual model (Figure 1 below) is presented to assess and determine the determinants of trust in the public accountant - SME relationship in Australia (Cherry, 2016).

Figure 1 - Conceptual Model for the Determinants of Trust in the Australian Public Accountant - SME Client Relationship

TRUST $=a+b_{1}$ LENGTH $+b_{2}$ FACE $+b_{3}$ ENGAGEMENT $+b_{4}$ ASSISTANCE $+b_{5}$ ADVISORY $+b_{6}$ ACCREDITATION $+b_{7}$ SIZE

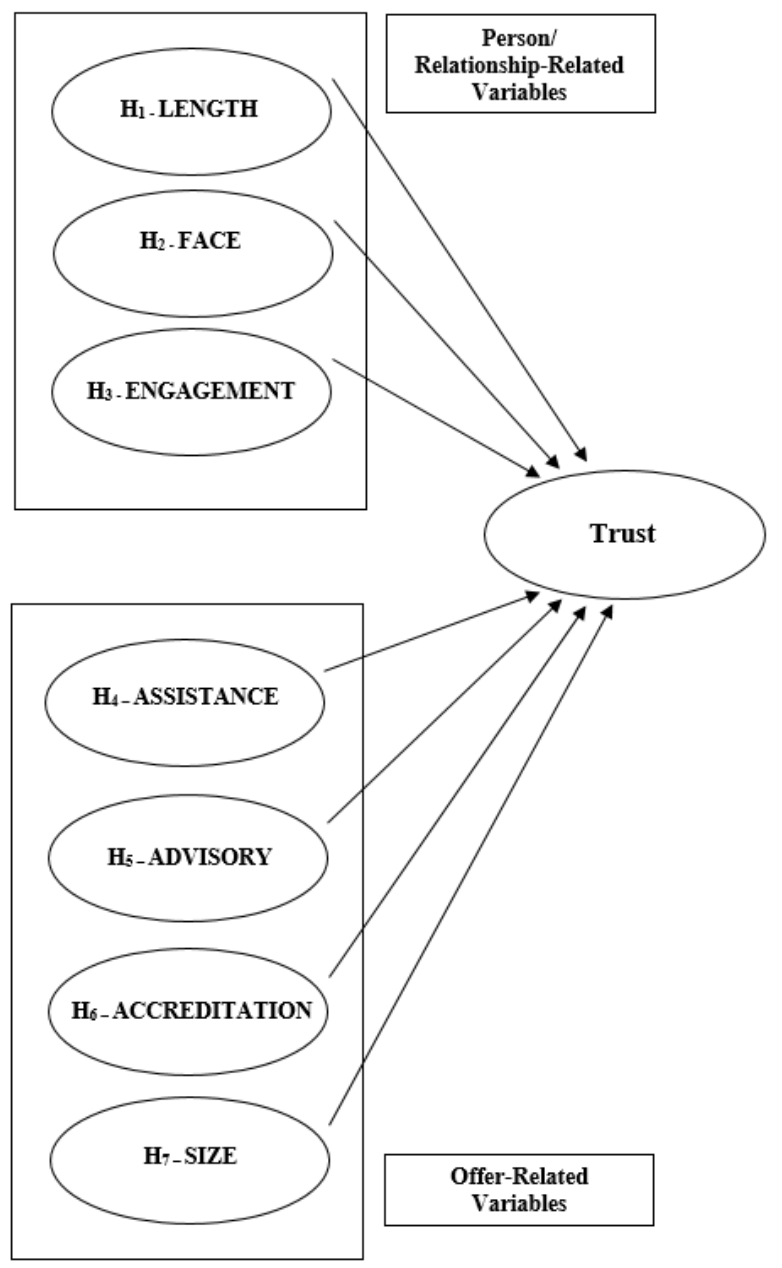

(Cherry, 2016, p. 18) 


\section{Methodology:}

This section presents the overall research approach, methodology and specific research design utilised to identify the determinants of trust in the Australian public accountant - SME client relationship. The majority of the reviewed papers (50\%) (Bennett \& Robson, 2005; Berry et al., 2006; Chumpitaz Caceres \& Paparoidamis, 2007; Coulter \& Coulter, 2002; Dyer \& Chu, 2011; Gounaris, 2005; Jay \& Schaper, 2003; Leung et al., 2008; Sharif et al., 2005; Theron, Terblanche, \& Boshoff, 2008) sought to; test empirical models and examine the relationship between independent and dependent variables across a range of business to business relationships. These papers identified a significant positivism bias, underpinned by objective realism ontology and dualist and objective epistemology, with consistent use of experimental and manipulative (quantitative) approaches. Bryman (1984, p. 77) identifies quantitative methodologies as having a, "...preoccupation with operational definitions, objectivity, replicability, causality, and the like." The social survey is also identified as the preferred instrument of quantitative or positivist approach.

The work by Hanson and Grimmer (2007) identified a significant quantitative orientation in scholarly marketing articles (across the period 1993 to 2002). Approximately 46\% of articles employed quantitative research in some form, which was similar to our experience (refer above). In addition to the strengths of quantitative methodologies (for example, ability to test and validate frameworks and hypotheses, can generalise findings, relatively quick collection and analysis of data, useful for large samples, provides quantitative/numerical data and the like), the Hanson and Grimmer (2007) paper provides three interesting arguments to explain their findings. These included historical, social and practical arguments. From historical and social perspectives, they suggest that the positivist tradition of important centres such as Harvard University Graduate School of business and the University of Wisconsin have influenced other marketing schools. On the practical level, the word limits on journal articles was felt to encourage the use of quantitative approaches. The limitations of the positivist approach are reflected in the concerns with quantitative methodologies (Sarantakos, 2005). These include, but are not limited to; defining reality as objective, bias of hypotheses restricting research options and forcing opinions upon respondents.

The above papers provided significant guidance on the paradigmatic approach of this research, to identify the determinants of trust in the Australian public accountant - SME client relationship. These papers provided further refinement of the independent variables in this research. The author's ontological assumption is that of Realism, with knowledge gained assumed to be objective reality. The proposed research paradigm is therefore concluded to be Positivism. A Dualist and Objective epistemology is assumed, as the investigator and the investigated are assumed to be independent entities. The Positivist approach relies on quantitative/experimental methods, with surveys, longitudinal, cross-sectional, correlational, experimental, quasiexperimental and ex-post facto research methods (Dash, 2005). This review of prior scholarly paradigmatic approaches and linking this analysis to the proposed research question and hypotheses (Easterby-Smith, Thorpe, \& Lowe, 1991; Guba \& Lincoln, 1998; Sarantakos, 2005) resulted in a quantitative methodology being chosen. 
As this research intended to identify the antecedents, or determinants, of trust in the Australian public accountant - SME client relationship a quantitative methodology is recommended. An experimental and manipulative methodology, via the use of a quantitative survey or questionnaire was also utilised.

In Australia, SME organisations have been classified by the Australian Bureau of Statistics (ABS) in the following manner (ABS, 2017).

Small employing businesses - businesses with employment of fewer than 20 persons and includes micro employing businesses (businesses with employment of fewer than 5 persons) \& other employing small businesses (businesses with employment of 5 to fewer than 20 persons).

Medium employing businesses - businesses with employment of 20 to fewer than 200 persons.

To ensure statistical rigour, the research required a minimum of 384 Australian SME organisations to be surveyed, via a web-based questionnaire, to ensure a confidence interval of $5 \%$. The questionnaire was piloted prior, to confirm reliability and validity. A five-point Likert scale was employed to assess respondents' attitudes in a precise manner by combining responses across a range of responses. To ensure rigour, the following measurement table (refer Appendix) links each survey question with relevant academic sources, for the dependent variable (trust), as well as each of the seven independent variables (refer Figure 1). Respondents were drawn from the peak business bodies (both general industry and industry specific) which represent the majority of Australia's SME organisations, as well as commercial databases and the authors' SME network. Additionally, a pilot study was undertaken to test the questionnaire; wording, sequencing, layout and to gain familiarity with respondents, estimate response rates and questionnaire completion time and ultimately test analysis procedures. In the final survey, there were four hundred and thirty two (432) SME respondents to the Australia-wide online survey (above the minimum 384 requirement detailed above). The software programme utilised for data analysis was IBM SPSS Statistics for Windows, Version 20.0.

\section{Results:}

Initially, a data reduction exercise was undertaken on the dependent variable (TRUST) and independent variables (LENGTH, FACE, ENGAGEMENT, ASSISTANCE, ADVISORY, ACCREDITATION \& SIZE), before carrying out multiple linear regression to establish the determinants of trust in the Australia public accountant - SME client relationship. According to Hair, Black, Babin, and Anderson (2010) factor analysis can be used to identify representative variables from a larger set of variables. The data reduction exercise, to reduce the number of items within multi-item constructs, was undertaken to allow for more efficient multivariate analyses. Principal component analysis and exploratory factor analysis were utilised for constructs with multiple items (i.e. the dependent variable, Trust, and the following independent variables, Engagement $\left(\mathrm{H}_{3}\right)$, Assistance $\left(\mathrm{H}_{4}\right)$, Advisory $\left(\mathrm{H}_{5}\right)$ ) (Hair et al., 2010, p. 15). Multidimensional measures were deemed appropriate for "attitudinal and behavioural aspects" in relation to trust (Baumann, Burton, Elliott, \& Kehr, 2007, p. 105). The findings of the data reduction exercises for the dependent variable and independent variables with multiple items are summarised below in Tables 1 through 7 . Only items which were shown to contribute significantly to each construct have been reported in these tables. That is, they summarise the findings of the data reduction exercises. 


\section{Dependent Variable - Data Reduction}

The thirteen measures (refer Appendix) for the dependent variable, trust, were found to reduce to three separate trust variables, identified as TRUST $_{1}$, TRUST $_{2}$ and TRUST 3 below. This outcome is not surprising, as the trust definition utilised (Cherry, 2016), speaks to three specific elements, covering; confidence, not exploiting vulnerabilities and acting proactively in the client's interest (refer Figure 2 below). This multi-dimensionality is also consistent with the Dowell et al. (2015) findings relating to cognitive and affective trust elements.

Figure 2 - Confidence, Vulnerability \& Proactivity Trust Elements

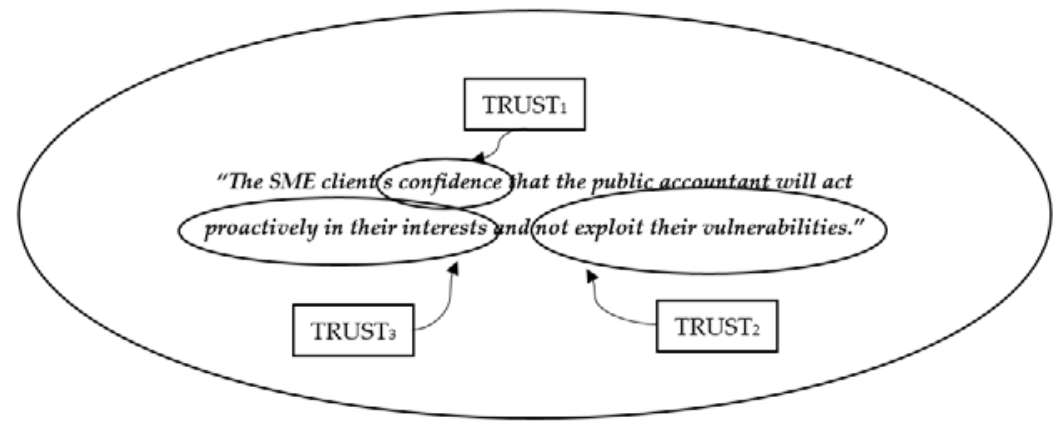

Table 1 - TRUST (confidence)- Dependent Variable Data Reduction

\begin{tabular}{|llllc|}
\hline $\begin{array}{l}\text { Factor } \\
\text { Loading }\end{array}$ & Name & Question & Mean & $\begin{array}{c}\text { Std } \\
\text { Dev }\end{array}$ \\
\hline $\mathbf{0 . 8 5 9}$ & Confidence & My public accountant has my full confidence & 4.33 & 0.83 \\
\hline $\mathbf{0 . 8 5 8}$ & $\begin{array}{l}\text { Critical } \\
\text { Information }\end{array}$ & $\begin{array}{l}\text { My public accountant never withholds critical } \\
\text { information that might affect my decision- } \\
\text { making }\end{array}$ & 4.33 & 0.82 \\
\hline $\mathbf{0 . 7 0 2}$ & Interest & $\begin{array}{l}\text { My public accountant always acts in the best } \\
\text { interests of my business }\end{array}$ & 4.33 & 0.81 \\
\hline $\mathbf{0 . 5 7 6}$ & All times & $\begin{array}{l}\text { My public accountant can be trusted at all } \\
\text { times }\end{array}$ & 4.42 & 0.79 \\
\hline $\mathbf{0 . 5 2 9}$ & Concern & $\begin{array}{l}\text { My public accountant is always honest \& } \\
\text { truthful }\end{array}$ & 4.14 & 0.92 \\
\hline $\mathbf{0 . 4 2 9}$ & Needs & $\begin{array}{l}\text { My public accountant takes care of my needs } \\
\text { as a client }\end{array}$ & 4.25 & 0.85 \\
\hline
\end{tabular}

Note: Cronbach's alpha (standardised) $=0.930$ 
The above data reduction exercise (Table 1) identified the first of three trust dependent variables, from the initial single proposed trust dependent variable. This TRUST $_{1}$ relates to the confidence component of trust, per the definition above.

Table 2 - TRUST $_{2}$ (vulnerabilities) - Variable Data Reduction

\begin{tabular}{|lllllll|}
\hline $\begin{array}{l}\text { Factor } \\
\text { Loading }\end{array}$ & Name & Question & Mean & $\begin{array}{l}\text { Std } \\
\text { Dev }\end{array}$ \\
\hline $\mathbf{0 . 9 4 6}$ & $\begin{array}{l}\text { Client } \\
\text { Focus }\end{array}$ & $\begin{array}{l}\text { My public accountant puts my business's } \\
\text { interests above their own }\end{array}$ & 3.57 & 0.97 \\
\hline
\end{tabular}

Cronbach's alpha (standardised) $=\mathrm{N} / \mathrm{A}$, as a single item

The dependent variable data reduction exercise (Table 2) also identified a second variable, TRUST $_{2}$, as a single measure variable, relating to the not exploiting vulnerabilities component of trust, per the definition above.

Table 3 - TRUST 3 (proactivity) - Variable Data Reduction

\begin{tabular}{|llllll|}
\hline $\begin{array}{l}\text { Factor } \\
\text { Loading }\end{array}$ & Name & Question & Mean & $\begin{array}{l}\text { Std } \\
\text { Dev }\end{array}$ \\
\hline $\mathbf{- 0 . 9 4 7}$ & Fulfil & $\begin{array}{l}\text { My public accountant can be relied upon to fulfil } \\
\text { their commitments }\end{array}$ & 4.30 & 0.78 \\
\hline $\mathbf{- 0 . 7 2 8}$ & Integrity & $\begin{array}{l}\text { My public accountant has a high level of } \\
\text { integrity }\end{array}$ & 0.50 & 0.69 \\
\hline $\mathbf{- 0 . 6 7 3}$ & Credible & $\begin{array}{l}\text { My public accountant can be regarded as } \\
\text { credible }\end{array}$ & $\begin{array}{l}\text { My public accountant is sincere in their dealings } \\
\text { with my business }\end{array}$ \\
\hline $\mathbf{- 0 . 4 8 9}$ & Sincere & \begin{tabular}{l} 
M.50 \\
\hline
\end{tabular}
\end{tabular}

Note: Cronbach's alpha (standardised) $=0.913$

The data reduction exercise (Table 3 ) identified a final dependent trust variable, TRUST $_{3}$, which appears to relate to the requirement to serve proactively in the client's interest, per the trust definition above.

\section{Independent Variable - Data Reduction}

In a similar fashion to that undertaken above with the dependent variable, trust, data reduction exercises were carried out for each of the multi-item independent variables, commencing with Engagement (Tables 4 and 5 below). 
AABFJ | Volume 12, no. 1, 2018

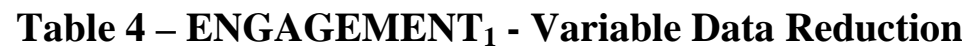

\begin{tabular}{|llllc|}
\hline $\begin{array}{l}\text { Factor } \\
\text { Loading }\end{array}$ & Name & Question & Mean & $\begin{array}{c}\text { Std } \\
\text { Dev }\end{array}$ \\
\hline $\mathbf{0 . 9 3 9}$ & Committed & $\begin{array}{l}\text { I am very committed to my relationship with my } \\
\text { public accountant }\end{array}$ & 4.08 & 0.87 \\
\hline $\mathbf{0 . 8 9 6}$ & Indefinitely & $\begin{array}{l}\text { I intend to maintain my relationship with my } \\
\text { public accountant indefinitely }\end{array}$ & 4.02 & 0.94 \\
\hline $\mathbf{0 . 8 7 2}$ & Loyalty & I have strong loyalty to my public accountant & 3.97 & 0.94 \\
\hline $\mathbf{0 . 8 3 8}$ & Maintain & $\begin{array}{l}\text { I make a good effort to maintain my relationship } \\
\text { with my public accountant }\end{array}$ & 4.04 & 0.78 \\
\hline $\mathbf{0 . 8 3 7}$ & Commercial & $\begin{array}{l}\text { I enjoy a strong commercial relationship with } \\
\text { my public accountant }\end{array}$ & 3.92 & 0.93 \\
\hline
\end{tabular}

Note: Cronbach's alpha (standardised) $=0.932$

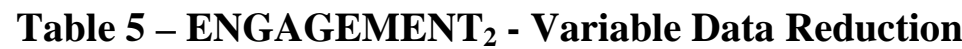

\begin{tabular}{|llllc|}
\hline $\begin{array}{l}\text { Factor } \\
\text { Loading }\end{array}$ & Name & Question & Mean & $\begin{array}{c}\text { Std } \\
\text { Dev }\end{array}$ \\
\hline $\mathbf{0 . 9 9 2}$ & Personal & $\begin{array}{l}\text { I enjoy a strong personal relationship with } \\
\text { my public accountant, outside our } \\
\text { commercial relationship }\end{array}$ & 2.95 & 1.22 \\
\hline $\mathbf{0 . 5 1 7}$ & $\begin{array}{l}\text { Client } \\
\text { Commitment }\end{array}$ & $\begin{array}{l}\text { I am willing to 'travel the extra mile' to } \\
\text { maintain my relationship with my public } \\
\text { accountant }\end{array}$ & 3.50 & 1.05 \\
\hline
\end{tabular}

Note: Cronbach's alpha (standardised) $=0.758$

After data reduction, the seven items relating to engagement, or relationship more broadly, split into two independent variables. The first, ENGAGEMENT ${ }_{1}$, with five items in the measure (refer Table 4 above, relates primarily to the commercial relationship between the SME and their public accountant. The second, ENGAGEMENT 2 , (refer Table 5 above speaks more specifically to the relationship beyond the commercial, moving more towards a more personal, intimate relationship. 
Cherry, McGrath \& Baumann | Client Intimacy \& Performance Advice

Table 6 - ASSISTANCE 1 - Variable Data Reduction

\begin{tabular}{|llllc|}
\hline $\begin{array}{l}\text { Factor } \\
\text { Loading }\end{array}$ & Name & Question & Mean & $\begin{array}{c}\text { Std } \\
\text { Dev }\end{array}$ \\
\hline $\mathbf{0 . 8 5 6}$ & Alternatives & $\begin{array}{l}\text { My public accountant provides well thought } \\
\text { out alternatives suited to my business's } \\
\text { unique needs }\end{array}$ & 3.39 & 1.07 \\
\hline $\mathbf{0 . 7 9 9}$ & Operate & $\begin{array}{l}\text { My public accountant provides me with } \\
\text { advice about how to operate my business }\end{array}$ & 3.30 & 1.10 \\
\hline $\mathbf{0 . 7 9 7}$ & Working & $\begin{array}{l}\text { My public accountant takes the time to } \\
\text { prepare working papers and notes for me to } \\
\text { evaluate }\end{array}$ & 3.61 & 1.06 \\
\hline $\mathbf{0 . 7 6 2}$ & Lapers & $\begin{array}{l}\text { My public accountant has expressed a desire } \\
\text { to develop a long-term business relationship } \\
\text { with me }\end{array}$ & 3.86 & 0.95 \\
\hline $\mathbf{0 . 7 2 1}$ & Interpret & $\begin{array}{l}\text { My public accountant helps me interpret } \\
\text { ambiguous or grey areas of tax laws in my } \\
\text { favour }\end{array}$ & 3.95 & 0.92 \\
\hline
\end{tabular}

Note: Cronbach's alpha (standardised) $=0.849$

Table 7 - ASSISTANCE 2 - Variable Data Reduction

\begin{tabular}{|llllc|}
\hline $\begin{array}{l}\text { Factor } \\
\text { Loading }\end{array}$ & Name & Question & Mean & $\begin{array}{c}\text { Std } \\
\text { Dev }\end{array}$ \\
\hline $\mathbf{0 . 9 8 8}$ & ATO & $\begin{array}{l}\text { My public accountant believes that the } \\
\text { Australian Taxation Office is actually their } \\
\text { client, not my business }\end{array}$ & 3.80 & 1.02 \\
\hline
\end{tabular}

Note: Cronbach's alpha (standardised) $=$ N/A, as a single item

Data reduction of the assistance independent variable (which included six items) yielded two separate variables, ASSISTANCE ${ }_{1}$ and ASSISTANCE $_{2}$, per Tables 6 \& Table 7 above. ASSISTANCE $_{1}$ (Gopichandran \& Chetlapalli) primarily relates to the provision of compliance services to the SME client. The second, ASSISTANCE 2 (single measure), asks SME clients to make an assessment relating to the public accountant's primary client - the SME or the ATO? 
Table 8 - ADVISORY 1 Variable Data Reduction

\begin{tabular}{|llllc|}
\hline $\begin{array}{l}\text { Factor } \\
\text { Loading }\end{array}$ & Name & Question & Mean & Std \\
\hline $\mathbf{0 . 8 9 3}$ & Define & $\begin{array}{l}\text { My public accountant works with me to define } \\
\text { my particular business needs }\end{array}$ & 3.19 & 1.10 \\
\hline $\mathbf{0 . 8 8 3}$ & Improve & $\begin{array}{l}\text { My public accountant helps me improve the } \\
\text { performance of my business }\end{array}$ & 3.11 & 1.13 \\
\hline $\mathbf{0 . 8 6 5}$ & Customised & $\begin{array}{l}\text { My public accountant provides extremely } \\
\text { customized services to my business }\end{array}$ & 3.19 & 1.08 \\
\hline $\mathbf{0 . 8 5 1}$ & Effective & $\begin{array}{l}\text { I am confident in my public accountant's ability } \\
\text { to provide effective business improvement } \\
\text { advice }\end{array}$ & 3.42 & 1.07 \\
\hline $\mathbf{0 . 8 5 0}$ & Managerial & $\begin{array}{l}\text { I am happy to approach my public accountant to } \\
\text { assist with managerial problems within my } \\
\text { business }\end{array}$ & 3.23 & 1.15 \\
\hline $\mathbf{0 . 7 3 6}$ & Proactive & $\begin{array}{l}\text { My public accountant is proactive in suggesting } \\
\text { ways to improve my business's overall } \\
\text { performance }\end{array}$ & 3.20 & 1.04 \\
\hline $\mathbf{0 . 6 8 2}$ & Grow & $\begin{array}{l}\text { My public accountant provides advice on how to } \\
\text { grow my business }\end{array}$ & 2.76 & 1.03 \\
\hline
\end{tabular}

Note: Cronbach's alpha (standardised) $=0.937$

Table 9-ADVISORY 2 Variable Data Reduction

\begin{tabular}{|llllc|}
\hline $\begin{array}{l}\text { Factor } \\
\text { Loading }\end{array}$ & Name & Question & Mean & $\begin{array}{c}\text { Std } \\
\text { Dev }\end{array}$ \\
\hline $\mathbf{0 . 9 3 9}$ & $\begin{array}{l}\text { Beyond } \\
\text { compliance }\end{array}$ & $\begin{array}{l}\text { My public accountant offers services, beyond } \\
\text { tax compliance advice, to my business }\end{array}$ & 3.36 & 1.15 \\
\hline $\mathbf{0 . 8 9 0}$ & $\begin{array}{l}\text { Broader } \\
\text { advisory }\end{array}$ & $\begin{array}{l}\text { My public accountant offers broader business } \\
\text { advisory services to my business }\end{array}$ & 3.11 & 1.11 \\
\hline
\end{tabular}

Note: Cronbach's alpha (standardised) $=0.851$

Two factors were identified within the advisory variable (ADVISORY 1 and ADVSORY $_{2}$ ). The first relates to the degree of advisory services offered and accepted/utilised by the public accountant to the SME client. The second, speaks to the broader advisory offers available from the public accountant. That is, their availability primarily, rather than any specific comment on their quality. 


\section{Modified Trust Models}

As a consequence of the above data reduction exercises, three trust models have been developed, finessing the initial conceptual model proposed to describe trust in the Australian public accountant - SME client relationship (refer Figure 1). An overview of the modified, or updated, models, as informed by the data reduction exercise, follows below.

$$
\begin{gathered}
\text { TRUST }_{\mathbf{1}}=\mathrm{a}+\mathrm{b}_{1} \text { LENGTH }^{+} \mathrm{b}_{2} \text { FACE }+\mathrm{b}_{3} \text { ENGAGEMENT }_{1}+\mathrm{b}_{4} \text { ENGAGEMENT }_{2} \\
+\mathrm{b}_{5} \text { ASSISTANCE }_{1}+\mathrm{b}_{6} \text { ASSISTANCE }_{2}+\mathrm{b}_{7} \text { ADVISORY }_{1}+\mathrm{b}_{8} \text { ADVISORY }_{2} \\
+\mathrm{b}_{9}{\text { ACCREDITATION }+\mathrm{b}_{10} \text { SIZE }}
\end{gathered}
$$

Where TRUST $_{1}$ relates to the confidence component of trust, per the definition above. Refer to Table 1 above for further details on this variant of the trust dependent variable.

$$
\begin{aligned}
& \text { TRUST }_{2}=\mathrm{a}+\mathrm{b}_{1} \text { LENGTH } \mathrm{b}_{2} \text { FACE }+\mathrm{b}_{3} \text { ENGAGEMENT }_{1}+\mathrm{b}_{4} \text { ENGAGEMENT }_{2} \\
& +b_{5} \text { ASSISTANCE }_{1}+b_{6} \text { ASSISTANCE }_{2}+b_{7} \text { ADVISORY }_{1}+b_{8} \text { ADVISORY }_{2}+b_{9} \\
& \text { ACCREDITATION }+b_{10} \text { SIZE }
\end{aligned}
$$

Where TRUST $\mathbf{T}_{2}$ relates to the not exploiting vulnerabilities component of trust, per the definition above. Refer to Table 2 above for further details on this variant of the trust dependent variable.

$$
\begin{aligned}
& \text { TRUST }_{3}=a+b_{1} \text { LENGTH } \mathrm{b}_{2} \text { FACE }+\mathrm{b}_{3} \text { ENGAGEMENT }_{1}+\mathrm{b}_{4} \text { ENGAGEMENT }_{2} \\
& +b_{5} \text { ASSISTANCE }_{1}+b_{6} \text { ASSISTANCE }_{2}+b_{7} \text { ADVISORY }_{1}+b_{8} \text { ADVISORY }_{2}+b_{9} \\
& \text { ACCREDITATION }+b_{10} \text { SIZE }
\end{aligned}
$$

Where TRUST $_{3}$ relates to the proactively in the client's interest component of trust, per the definition above. Refer to Table 3 above for further details on this variant of the trust dependent variable.

The modified, or updated, independent variables, from the data reduction exercise above, are described as follows: 
ADVISORY $_{1} \quad$ Relates to the SME's confidence in the advisory services (i.e. beyond compliance services) offered by the public accountant.

ADVISORY $_{2}$ Relates to the availability of advisory services offerings by the public accountant.

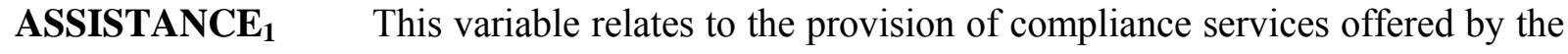
public accountant.

ASSISTANCE $_{2}$ This single item variable relates specifically to the degree to which the SME believes that their public accountant sees them as the client, versus the ATO.

ENGAGEMENT $_{1}$ This speaks to the commercial relationship between the accountant and their SME client.

ENGAGEMENT $_{2}$ This relates to the deeper, personal relationship that the public accountant has with the SME client.

\section{Predicting Trust}

The first of the updated trust models, TRUST 1 , (which relates to the confidence component of trust definition, refer above for the determinants of trust in the Australian public accountant SME client relationship was tested using multiple linear regression, with the results summarised in the tables below.

Table 10 - Predicting TRUST 1 (confidence): Multiple Regression Analysis

\begin{tabular}{|c|c|c|c|c|c|}
\hline Predictor & $\begin{array}{l}\text { Unstandardised } \\
\text { Coefficients }\end{array}$ & $\begin{array}{l}\text { Standard } \\
\text { Error }\end{array}$ & $\begin{array}{l}\text { Standardised } \\
\text { Coefficients } \\
\text { (beta) }\end{array}$ & $t$ & $p$ \\
\hline Constant & 1.132 & 0.138 & & 8.215 & $<0.001$ \\
\hline ENGAGEMENT $_{1}$ & 0.787 & 0.045 & 0.641 & 13.001 & $<0.001$ \\
\hline FACE & 0.115 & 0.027 & 0.155 & 4.192 & $<0.001$ \\
\hline ASSISTANCE $_{2}$ & 0.065 & 0.020 & 0.095 & 3.179 & 0.002 \\
\hline ADVISORY $_{1}$ & 0.100 & 0.040 & 0.131 & 2.482 & 0.013 \\
\hline
\end{tabular}

Notes: $R^{2}=0.671$, Adjusted $R^{2}=0.663$

Approximately 66 per cent (Adjusted $R^{2}=0.663$ ) of the variation in the modified TRUST 1 model can be explained by the variables in Table 10 above. This compares favourably with the Dyer and Chu (2011) paper, used as the theoretical framework for this research, which yielded and Adjusted $R^{2}$ result of 0.26 (or 26\%). Although ENGAGEMENT EN $_{2}$ and ASSISTANCE $_{1}$ significantly correlated with trust, they were not found to be statistically significant to trust after 
consideration of all other predictors. That is, the development of the relationship beyond the commercial engagement, nor the breadth of assistance provided were not found to be a significant determinant of TRUST ${ }_{1}$. LENGTH (of the commercial relationship), ACCREDITATION (IPA, CPA or CAANZ) and SIZE (of public accountancy practice) were

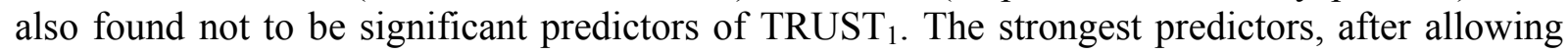
for the impacts of other predictors, were ENGAGEMENT ${ }_{1}$, followed (at some distance) by FACE. That is, for ENGAGEMENT ${ }_{1}$, the stronger the commercial engagement between the public accountancy firm and the SME, the higher the SME's trust in their public accountant (beta of 0.641).

For FACE, the hypothesis was that the higher the face-to-face interaction between the public accountant and the SME, the higher the SME's trust in the public accountant (beta of 0.155). ASSISTANCE $_{2}$, which related to the single question relating to the true client (SME or Australian Taxation Office (ATO)) was also found to be of significance (beta of 0.095). Finally, $\mathrm{ADVISORY}_{2}$, which speaks to the provision of advisory (or non-compliance services), was also of some significance (beta of 0.131). That is, two out of the three person/relationship-related variables were found to be significant determinants of trust in the Australian public accountant SME client relationship - especially ENGAGEMENT ${ }_{1}$ and significantly (but to a lesser extent) FACE. The other person/relationship-related variable, LENGTH, was not found to impact TRUST. The model concluded that the offer-related variables (ASSISTANCE 2 and ADVISORY $_{1}$ ) were found to contribute, although to a lesser extent than the above person/relationship-related variables, to trust in the Australian public accountant - SME client relationship. The residual statistics showed no issues relating to fit for this model.

The modified/updated TRUST $\mathbf{T}_{\mathbf{2}}$ model (which relates to the not exploiting vulnerabilities component of trust definition, refer above) for the determinants of trust in the Australian Public Accountant - SME client relationship was tested, with the results summarised in the tables below.

Table 11 - Predicting TRUST 2 (vulnerabilities): Multiple Regression Analysis

\begin{tabular}{|c|c|c|c|c|c|}
\hline Predictor & $\begin{array}{l}\text { Unstandardised } \\
\text { Coefficients }\end{array}$ & $\begin{array}{l}\text { Standard } \\
\text { Error }\end{array}$ & $\begin{array}{l}\text { Standardised } \\
\text { Coefficients } \\
\text { (beta) }\end{array}$ & $t$ & $p$ \\
\hline Constant & 0.489 & 0.262 & & 1.867 & 0.063 \\
\hline ENGAGEMENT $_{1}$ & 0.514 & 0.086 & 0.400 & 5.979 & $<0.001$ \\
\hline ADVISORY $_{1}$ & 0.223 & 0.077 & 0.209 & 2.914 & 0.004 \\
\hline ACCREDITATION & -0.081 & 0.036 & -0.089 & -2.230 & 0.026 \\
\hline ENGAGEMENT $_{2}$ & 0.103 & 0.052 & 0.105 & 2.004 & 0.046 \\
\hline FACE & 0.101 & 0.052 & 0.097 & 1.938 & 0.053 \\
\hline
\end{tabular}

Notes: $R^{2}=0.396$, Adjusted $R^{2}=0.381$

Approximately 38 per cent (Adjusted $R^{2}=0.381$ ) of the variation in the overall TRUST 2 model (which relates to the not exploiting vulnerabilities component of trust, per the definition above) can be explained by the variables in Table 11 above. Again, a favourable explanation of the overall variation against the Dyer and $\mathrm{Chu}$ (2011) finding. Although ASSISTANCE $_{1}$ significantly correlated with TRUST $_{2}$ it was not found to be statistically significant to overall 
TRUST $_{2}$ after consideration of all other predictors. That is, the breadth of compliance (or conformance) related offerings was not found to be a significant determinant of TRUST 2 . LENGTH (of the commercial relationship and SIZE (of public accountancy practice) were also

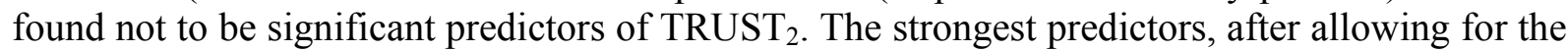
impacts of other predictors, were ENGAGEMENT ${ }_{1}$, followed by ADVISORY ${ }_{1}$, ACCREDITATION, ENGAGEMENT 2 and FACE (trending towards significance with a $p$ of 0.053 , per Table 11 above). That is, for ENGAGEMENT $1 / \mathrm{ENGAGEMENT}_{2}$, the broader the engagement (beyond the normal commercial client/professional services organisation engagement) between the public accountancy firm and the SME, the higher the SME's trust in their public accountant (beta of 0.400 and 0.105 respectively). ACCREDITATION of the public accountant was deemed a significant, although minor negative contributor to TRUST 2 . (beta of 0.089). For FACE, the hypothesis was that the higher the face-to-face interaction between the public accountant and the SME, the higher the SME's trust in the public accountant (beta of 0.097). The residual statistics showed no issues relating to fit for this model.

The updated TRUST T $_{3}$ model (which relates to the proactively in the client's interest component of trust definition, refer above) for the determinants of trust in the Australian Public Accountant - SME client relationship was tested, with the results summarised in the tables below.

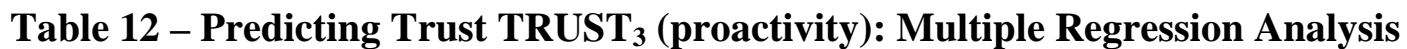

\begin{tabular}{|llllll|}
\hline Predictor & $\begin{array}{l}\text { Unstandardised } \\
\text { Coefficients }\end{array}$ & $\begin{array}{l}\text { Standard } \\
\text { Error }\end{array}$ & $\begin{array}{l}\text { Standardised } \\
\text { Coefficients } \\
\text { (beta) }\end{array}$ & $\boldsymbol{t}$ & $\boldsymbol{p}$ \\
\hline Constant & 1.859 & 0.139 & & 13.334 & $<0.001$ \\
\hline ENGAGEMENT $\mathbf{1}_{\mathbf{1}}$ & 0.506 & 0.046 & 0.614 & 11.075 & $<0.001$ \\
\hline FACE & 0.167 & 0.028 & 0.251 & 6.028 & $<0.001$ \\
\hline
\end{tabular}

Notes: $R^{2}=0.583$, Adjusted $R^{2}=0.573$

Approximately 57 per cent (Adjusted $R^{2}=0.573$ ) of the variation in the overall TRUST 3 model (which relates to the proactively in the client's interest component of trust definition, refer above) can be explained by the variables in Table 12 above. Again, a favourable explanation of the overall variation against the Dyer and Chu (2011) Adjusted $R^{2}$ finding $(0.26$ or 26\%). Although ENGAGEMENT ${ }_{2}$ and ASSISTANCE And ADVISORY $_{1}$ significantly correlated with TRUST $_{3}$, they were not found to be statistically significant to overall TRUST $_{3}$ after consideration of all other predictors. That is, the development of the relationship beyond the commercial engagement, breadth of compliance offers nor the provision of advisory (noncompliance offerings) were not found to be a significant determinant of TRUST 3 . LENGTH (of the commercial relationship), ACCREDITATION (IPA, CPA or CAANZ) and SIZE (of public accountancy practice) were also found not to be significant predictors of TRUST Th $_{3}$ The strongest predictors, after allowing for the impacts of other predictors, were ENGAGEMENT ${ }_{1}$, followed (at some distance) by FACE. That is, for ENGAGEMENT 1 , the stronger the commercial engagement between the public accountancy firm and the SME, the higher the SME's trust in their public accountant (beta of 0.614). For FACE, the hypothesis was that the higher the face-toface interaction between the public accountant and the SME, the higher the SME's trust in the public accountant (beta of 0.251). That is, two out of the three person/relationship-related variables were found to be significant determinants of trust in the Australian public accountant - 
SME client relationship - especially ENGAGEMENT ${ }_{1}$ and significantly (but to a lesser extent) FACE. The other person/relationship-related variable, LENGTH, was not found to impact TRUST $_{3}$. The model concluded that none of the offer-related variables (ASSISTANCE 1 \& 2 , ADVISORY $_{1 \& 2}$, ACCREDITATION nor SIZE) were found to contribute significantly to trust in the Australian public accountant - SME client relationship. The residual statistics showed no issues relating to fit for this model.

The multiple regression analysis relating to the confidence (TRUST ( $_{\mathbf{1}}$ ) element of the trust

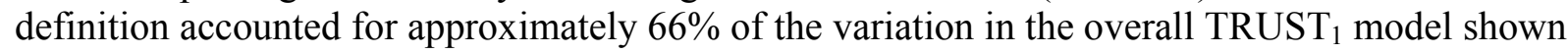
in Figure 3 below.

Figure 3 - TRUST 1 (confidence) Model

$$
\begin{gathered}
\text { TRUST }_{1}=1.132+0.641\left(\text { ENGAGEMENT }_{1}\right)+0.155(\text { FACE })+ \\
\text { 0.131 }\left(\text { ADVISORY }_{1}\right)+0.095\left(\text { ASSISTANCE }_{2}\right)
\end{gathered}
$$

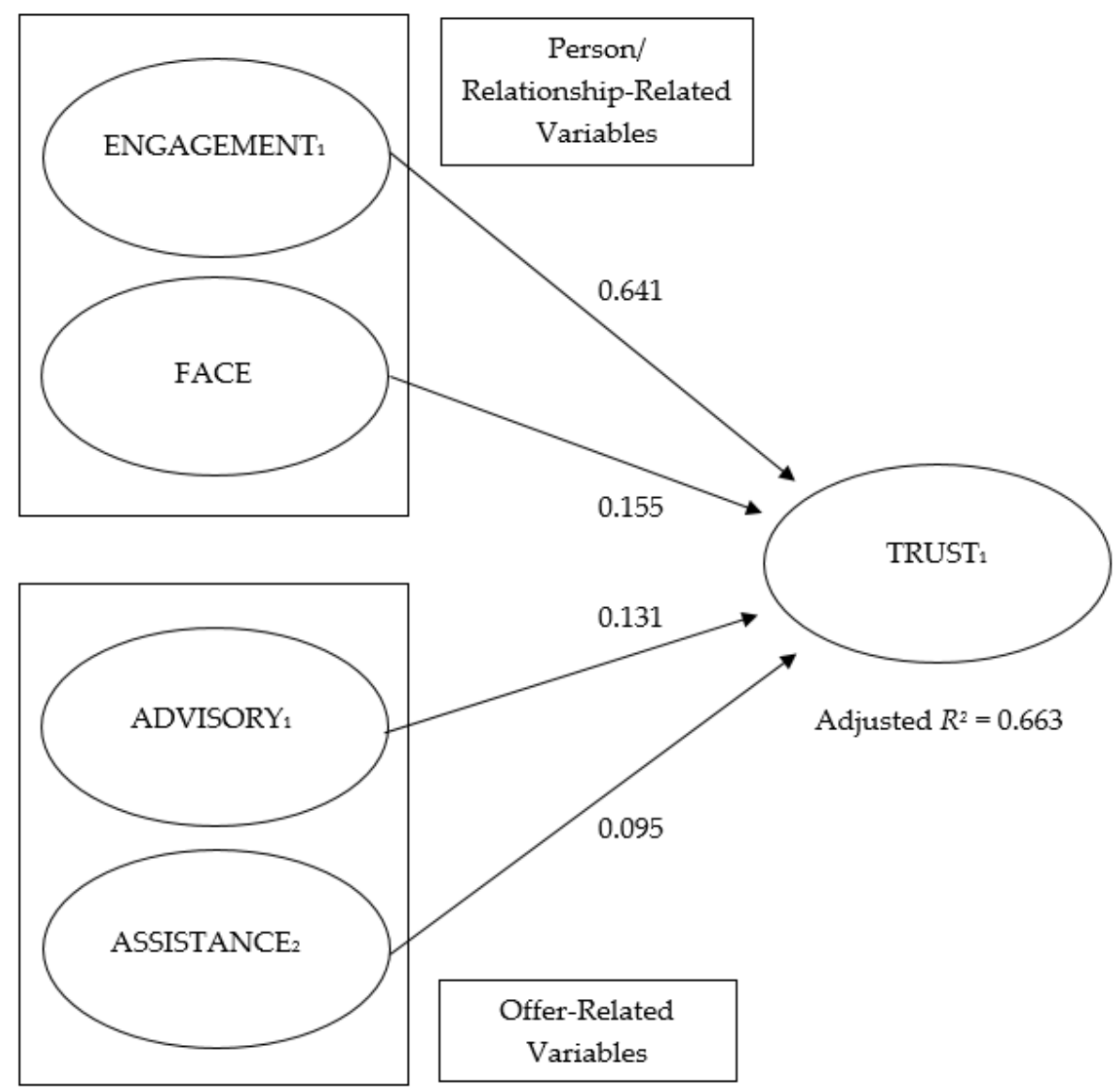

That is, the most significant predictor of the confidence element of SME trust, Australia-wide, relates to the depth of the commercial relationship between the SME client and their public accountant (ENGAGEMENT ${ }_{1}$ ). The next most significant contributor is the degree of face-to- 
face contact between the SME client and their public accountant (FACE). This is followed by the SME client's confidence in the advisory services offered by the public accountant $\left(\right.$ ADVISORY $\left._{1}\right)$ and lastly, the degree to which the SME believes their public accountant sees them as the client, versus the ATO (ASSISTANCE 2 ). In summary, the level of confidence a SME client has in their public accountant is most significantly positively impacted by the; depth of the commercial relationship, followed by the degree of face-to-face contact, the confidence in the advisory services offered and the provision of compliance services offered.

The multiple regression analysis relating to the not exploiting vulnerabilities (TRUST $_{2}$ ) element of the trust definition accounted for $38 \%$ of the variation in the overall TRUST model $_{2}$ shown in Figure 4 below.

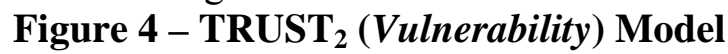

$$
\begin{gathered}
\text { TRUST }_{2}=0.489+0.400\left(\text { ENGAGEMENT }_{1}\right)+0.209\left(\text { ADVISORY }_{1}\right)+ \\
0.105\left(\text { ENGAGEMENT }_{2}\right)+0.097(\text { FACE })-0.089(\text { ACCREDITATION })^{-0}
\end{gathered}
$$

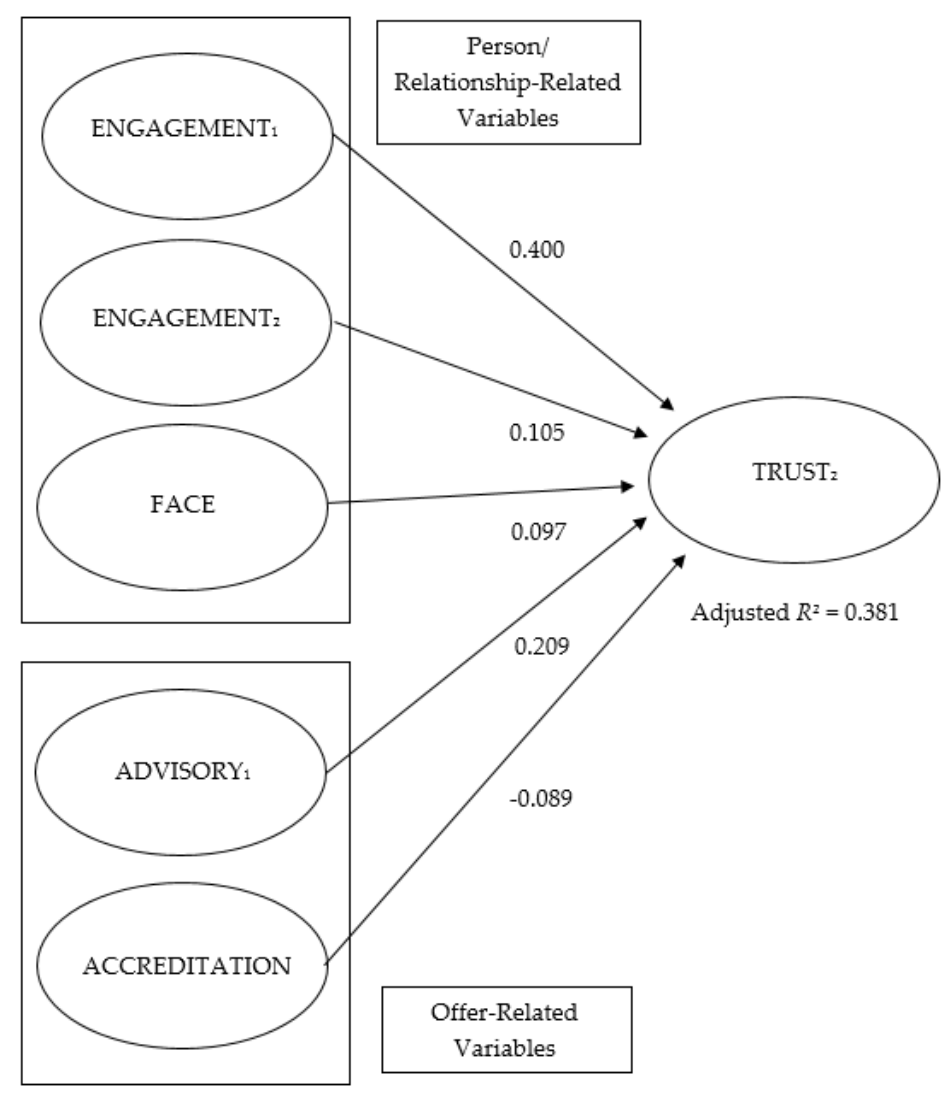

That is, the most significant predictor of the not exploiting vulnerabilities element of SME trust, Australia-wide, again relates to the breadth and depth of the commercial relationship $\left(\right.$ ENGAGEMENT $_{1}$ ) between the SME client and their public accountant. Similar to TRUST 1 above, the client's confidence in the provision of advisory services (ADVISORY ${ }_{1}$ ) and face-toface time (FACE) also featured in this model. However, the deeper, personal relationship 
(ENGAGEMENT ${ }_{2}$ ) was also identified as significant in explaining TRUST 2 . Additionally, the accountant's accreditation body (ACCREDITATION) was found to have a minor, negative impact on the not exploiting vulnerabilities element of trust.

The multiple regression analysis relating to the acting proactively in the client's interest (TRUST $_{3}$ ) element of the trust definition accounted for $57 \%$ of the variation in the overall TRUST $_{3}$ model shown in Figure 5 below.

Figure 5 - TRUST 3 (Proactivity) Model

TRUST $_{3}=1.859+0.614\left(\right.$ ENGAGEMENT $\left._{1}\right)+0.251($ FACE $)$

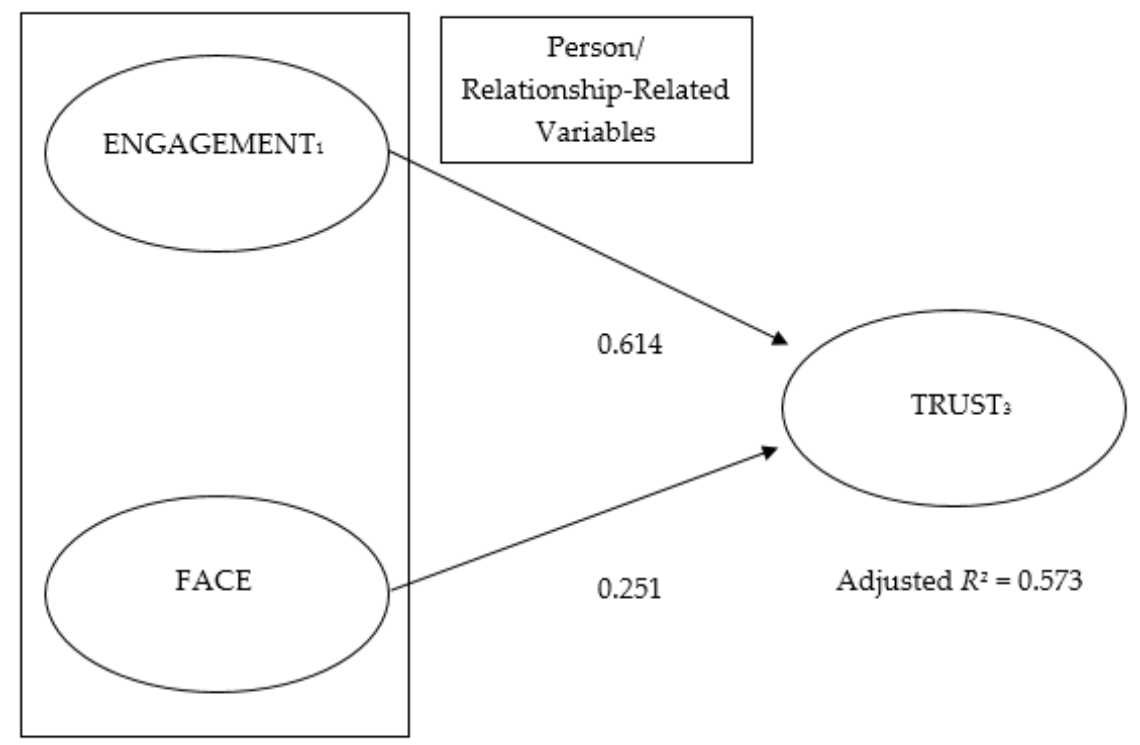

Again, the most significant predictor of the acting proactively in the client's interest element of SME trust, Australia-wide (47\% from New South Wales, 22\% Victoria, 15\% Queensland, 7\% Western Australia, 6\% South Australia, with the remaining 9\% from Tasmania, Northern Territory and the Australian Capital Territory) was the breadth and depth of the commercial relationship enjoyed by the SME client with their public accountant (ENGAGEMENT $\left.{ }_{1}\right)$. The only other predictor was the degree of face-to-face contact between the two parties. This also featured across the other two trust models $\left(\right.$ TRUST $_{1} \&$ TRUST $_{2}$ ).

\section{Discussion:}

Each of the three trust models identified and tested showed that the depth and breadth of the commercial relationship, client intimacy, and degree of face-to-face contact were important positive contributors to trust (ENGAGEMENT 1 \& FACE respectively), for all models. Confidence in the advisory services, i.e. performance services rather than conformance services, offered by public accountants (i.e. beyond compliance services) was also seen to be significant for the TRUST $_{1}$ (confidence) and TRUST 2 (not exploiting vulnerabilities) models. TRUST 1 also identified the degree to which the SME believes that their public accountant sees them as the 
client, versus the ATO (ASSISTANCE ). The TRUST $_{3}$ model had the deeper, personal relationship as a positive trust predictor (ENGAGEMENT ${ }_{2}$ ) and accreditation body as a minor negative predictor (ACCREDITATION). Overall, across each trust model, the most important predictors of SME trust in their public accountants related to the breadth and depth of the commercial engagement, or client intimacy, between the two parties and the degree of face-toface time in that relationship. This can also be described as the degree of investment made by each party to the overall relationship.

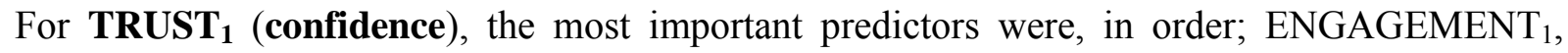

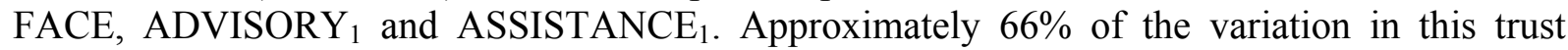
model was described by variables above. The two most important predictors (ENGAGEMENT $_{1}$ \& FACE) are what was defined as person/relationship-related variables. Engagement in the above context speaks to the breadth and depth of the commercial relationship between the SME client and their primary contact within the public accountancy practice, often a partner or principal. That is, the level of relationship they enjoy with one another. The next most significant predictor of confidence trust was the degree of face to face contact between the parties (with increased face to face contact leading to increased trust). The next two predictors, less significant than the person/relationship-related predictors described above, relate to what has been defined as offer-related variables.

The first of these, the SME's confidence in the public accountant's advisory service offering was seen to be significant. And finally, for this confidence trust construct, the more of the compliance-related services utilised by the client, the higher the level of trust. These findings confirm the anecdotal insights into potential trust determinants postulated by Blackburn et al. (2010). They suggest the development of an ongoing relationship, over time, through the provision of compliance services, social rapport, empathy and the provision of business advisory services. Relationship, social rapport and empathy equate to the person-relationship-related variables described above (i.e. ENGAGEMENT 1 \& FACE). Provision of compliance services and business advisory services relate to the offer-related services utilised in this research work (or ADVISORY $_{1} \&$ ASSISTANCE $_{2}$ in the context of the findings above). The Dyer and Chu (2011) findings primarily showed that process-based predictors of trust were strongly supported. In the context of this study, these refer to the major offer-related variables, which for TRUST ${ }_{1}$ were the ADVISORY 1 and ASSISTANCE 2 predictors. Dyer and Chu (2011) found that the embeddedness factor (person/relationship-related variables in this study, ENGAGEMENT $_{1} \&$ FACE above) was only important for Japan and not US or Korea.

For TRUST $_{2}$ (not exploiting vulnerabilities), the person/relationship-related variables of ENGAGEMENT $_{1}$ and FACE were again found to be significant (per TRUST 1 above). However, in this case ENGAGEMENT 2 was also seen to be significant. This variable speaks more specifically to the level of personal relationship (beyond their commercial engagement/relationship) enjoyed by the parties. This trust variable moves beyond the confidence element of trust and encompasses not exploiting the client's vulnerabilities. It is perhaps not surprising that the deeper level of personal relationship (beyond the commercial) could have some bearing on this particular trust element. From the offer-related variables standpoint, ADVISORY 1 was again found to be significant (per TRUST $_{1}$ above). It was also 
found that the accreditation body had a mildly negative impact on trust in this instance. That is, the more important the public accountant's accreditation body was to the client, the less trust in the relationship. This could speak to specific issues between the client and their accountant (for instance, service failings) bringing the accreditation body to the fore. It should also be noted that the variables above explained approximately $38 \%$ of this trust model (TRUST ${ }_{2}$ ). Additionally, the standard error of the estimate for this model was 0.78 , nearly double that of the TRUST ${ }_{1}$ (68\% explained and 0.41 standard error of the estimate) and $\mathrm{TRUST}_{2}(57 \%$ explained and 0.41 standard error of the estimate).

Finally, this model related to the reduced single item/question construct, the degree to which clients' agree that their accountant puts the client's business interests above their own (thus, not exploiting vulnerabilities). Again, person/relationship-related variables were shown to be the most significant determinants of trust, per TRUST 1 above. Offer-related variables were also significant, however generally to a lesser extent. The Dyer and Chu (2011) work showed the reverse of this, with offer-related variables (or the process-based perspective, as they refer to it) as the strongest predictors. Whilst this paper investigates trust in the business to business environment, it does so in the supplier-automaker context. Such a relationship relates to the provision of products, whereas in the Australian public accountant - SME client relationship, whilst also a B2B transaction, professional services are being transacted. In such service transactions, marketing mix matters relating to people, process and physical evidence become important to the overall relationship (Armstrong, Adam, Denize, \& Kotler, 2012; Kotler \& Keller, 2012). That is, the very nature of professional service relationships (intangibility, inseparability, variability and perishability of the service offering) demands a shift in focus towards person/relationship-related areas. This is not to suggest that offer-related variables are not important, just that person/relationship-related are brought further into relief in the professional services context.

The third trust model, TRUST 3 , which relates to the public accountant's proactivity, in the client's interest, also found that the person/relationship-related variables of ENGAGEMENT ${ }_{1}$ and FACE (per TRUST 1 and TRUST 2 above) were the strongest predictors of trust in the Australian public accountant - SME client relationship. In fact, only the above two person/relationship-related variables were found be of significance. Approximately $57 \%$ of the variation in this trust model was described by the variables above. The strong emphasis on relationship-related factors, as trust antecedents in the professional services context is again reinforced.

\section{Conclusion:}

The trust determinant findings above, across all models, reinforce the importance of person/relationship-related, or client intimacy variables in each instance. The level of professional or commercial engagement, or relationship development, supported by appropriate face-to-face contact were found to be most significant predictors of trust in the Australian public accountant - SME client relationship. Offer-related variables; primarily the provision of (and the client's confidence in) advisory services were also found to be significant across two of the trust models tested. These findings were broadly in line with the major Australian work in this area, by Blackburn et al. $(2010 ; 2014)$. However, this paper work postulated the importance of the 
development of; an ongoing relationship over time, social rapport, empathy (person/relationshiprelated variables) and the provision of compliance and business advisory services (offer-related variables), as potential trust determinants. They did not confirm these propositions empirically, as has been undertaken in this research work. The Dyer and Chu (2011) work also spoke to person/relationship-related variables and offer-related variables as trust determinants in the B2B context. They referred to them respectively as embeddedness perspectives and process-based perspectives. Their area of research focused on the product-based offerings relating to the $\mathrm{B} 2 \mathrm{~B}$ supplier-automaker relationships. Their findings suggest offer-based variables as the most significant predictors of trust in the relationship. This research, whilst also considered $\mathrm{B} 2 \mathrm{~B}$, is focused on the service-based offerings of public accountants (a professional service). As mentioned above, the nature of professional service offers (versus traditional product offerings) demands a shift in focus towards person/relationship-related areas.

There are three potential broad audiences for the outcomes of this work; accounting practitioners, their SME clients and academics (Cherry, 2016). Accounting practitioners cover Australia's public accountants themselves, through to the various officially recognised bodies (CAANZ, CPA and IPA) which represent the industry. The findings relating to the published trust and role definitions and the importance of relationship-related variables as trust determinants may provide practitioners with insights into how better to service and develop the relationship with their SME client base. The importance of the development of broad and deep relationships (at both commercial/professional and personal levels) should not be understated. The growing importance of advisory related services (Berry et al., 2006; Kirby \& King, 1997) was also supported by the findings, which suggest that performance advice (rather than conformance or compliance services) is a significant trust predictor in the relationship. Such findings may have implications for the manner in which public accountants manage the relationships with their SME clients and indeed the service offerings provided. Such findings could also be of interest to the officially recognised accreditation bodies (CAANZ, CPA \& IPA), relating to their overall objectives of these bodies, as well as training and professional development offerings (client management and consulting capabilities as examples) to their membership.

Another beneficiary of these findings is likely to be SME clients of Australia's public accountants, through better understanding of the benefits which can accrue from a more effective relationship with their public accountant. There may be learnings for academia within and beyond Australia. Researchers may be provided with insights which provide the opportunity for further refinement and development of the relational models presented and development of the research in this area. The above findings may also have implications for the development and delivery of academic programmes in the professional accounting space, as well as required professional accreditation programmes and ongoing education. For example, the finding in relation to the importance of strong commercial and personal relationships may require increased focus on customer relationship management techniques within professional accounting undergraduate programmes. Additionally, the importance of advisory services as a trust determinant may also point towards the need for additional non-compliance offerings (for example, strategy development and implementation, consulting and the like), across tertiary professional accounting programmes. 
As a proportion of the Australian SME business owners sampled were drawn from the authors' database (13\% estimated), a convenience sample has been assumed and may be considered a limitation of this work. Additionally, whilst the four hundred and thirty two SME respondents broadly represented the Australian SME population, they did represent a heavier emphasis of News South Wales SMEs (at $47 \%$ of respondents, the convenience sample impact). Future work utilising a random sample may provide further, refined insights into the Australian public accountant - SME client relationship.

This research appears to represent the first, formal effort to identify the determinants of trust in the Australian public accountant - SME client relationship. These initial findings have shed some light on this important relationship, but should be considered a first step on this path. Therefore, further empirical work to develop the area of trust, indeed multi-dimensional trust, in this relationship is encouraged and recommended.

\section{References:}

ABS. (2017, 21 February 2017). 8165.0 - Counts of Australian Businesses, including Entries and Exits, Jun 2012 to Jun 2016. Retrieved from http://www.abs.gov.au/ausstats/abs@.nsf/mf/8165.0

ACCA. (2016). Drivers of Change and Future Skills. Retrieved from United Kingdom: http://www.accaglobal.com/content/dam/members-beta/docs/ea-patf-drivers-of-changeand-future-skills.pdf

Armstrong, G., Adam, S., Denize, S., \& Kotler, P. (2012). Principles of marketing (5th Edition ed.). Australia: Pearson Australia.

Australian Accountants Directory. (2017). About accountants. Retrieved from www.australianaccountantsdirectory.com.au

Baumann, C., Burton, S., Elliott, G., \& Kehr, H. M. (2007). Prediction of attitude and behavioural intentions in retail banking. International Journal of Bank Marketing, 25(2), 102-116. https://doi.org/10.1108/02652320710728438

Bennett, R. J., \& Robson, P. J. A. (2005). The advisor-SME client relationship: impact, satisfaction and commitment. Small Business Economics, 25, 255-271. https://doi.org/10.1007/s11187-003-6459-3

Berry, A. J., Sweeting, R., \& Goto, J. (2006). The effect of business advisers on the performance of SMEs. Journal of Small Business and Enterprise Development, 13.(1.), 33-47.

Blackburn, R. A., Carey, P., \& Tanewski, G. (2010). The role of trust, relationships and professional ethics in the supply of external business advice by accountants to SMEs. Paper presented at the Australian Centre for Financial Studies-Finsia Banking and Finance Conference. https://doi.org/10.2139/ssrn.1592342

Blackburn, R. A., Carey, P., \& Tanewski, G. (2014). Business advice by accountants to SMEs: relationship and trust. Paper presented at the Small Enterprise Association of Australia and New Zealand 27th Annual SEAANZ Conference.

Blois, K. J. (1999). Trust in business to business relationships: an evaluation of its status. Journal of Management Studies, 36(2), 197-215. https://doi.org/10.1111/1467-6486.00133

Bryman, A. (1984). The debate about quantitative and qualitative research: A question of method or epistemology? The British Journal of Sociology, 35(1), 75-92. https://doi.org/10.2307/590553 
CAANZ. (2013). What is a Chartered Accountant and what makes them different? Retrieved from www.charteredaccountants.com.au

Cherry, M. (2016). Accounting for Trust: A Conceptual Model for the Determinants of Trust in the Australian Public Accountant-SME Client Relationship. Australasian Accounting, Business and Finance Journal, 10(2), 3. https://doi.org/10.14453/aabfj.v10i2.2

Chumpitaz Caceres, R., \& Paparoidamis, N. G. (2007). Service quality, relationship satisfaction, trust, commitment and business-to-business loyalty. European journal of marketing, 41(7/8), 836-867. https://doi.org/10.1108/03090560710752429

Coulter, K. S., \& Coulter, R. A. (2002). Determinants of trust in a service provider: the moderating role of length of relationship. Journal of Services Marketing, 16(1), 35-50. https://doi.org/10.1108/08876040210419406

CPA-Australia. (2017). Definition of a public accounting service. Retrieved from www.cpaaustralia.com.au

Dash, N. (2005). Module: selection of the research paradigm and methodology. Retrieved from www.celt.mmu.ac.uk

DEWRSB. (1996). A portait of Australian of business: Results of the 1996 business longitudinal survey. Canberra: Commonwealth of Australia.

Dowell, D., Morrison, M., \& Heffernan, T. (2015). The changing importance of affective trust and cognitive trust across the relationship lifecycle: A study of business-to-business relationships. Industrial Marketing Management, 44, 119-130. https://doi.org/10.1016/j.indmarman.2014.10.016

Dyer, \& Chu. (2011). The determinants of trust in supplier-automaker relationships in the US, Japan, and Korea. Journal of International Business Studies, 42(1), 10-27.

Dyer, \& Ross. (2007). Advising the small business client. International Small Business Journal, 25(2), 130-151.

Easterby-Smith, M., Thorpe, R., \& Lowe, A. (1991). An introduction to management research: Sage Publications, London.

Gooderham, P. N., Tobiassen, A., Døving, E., \& Nordhaug, O. (2004). Accountants as sources of business advice for small firms. International Small Business Journal, 22(1), 5-22. https://doi.org/10.1177/0266242604039478

Gopichandran, V., \& Chetlapalli, S. K. (2013). Dimensions and Determinants of Trust in Health Care in Resource Poor Settings - A Qualitative Exploration. PLoS One, 8(7). https://doi.org/10.1371/journal.pone.0069170

Gounaris, S. P. (2005). Trust and commitment influences on customer retention: insights from business-to-business services. Journal of Business research, 58(2), 126-140. https://doi.org/10.1016/S0148-2963(03)00122-X

Guba, E., \& Lincoln, Y. (1998). Competing paradigms in qualitative resesarch. In N.K. Denzin \& Y.S. Lincoln (EDS): Thousand Oaks: Sage Publications.

Hair, J. F., Black, W. C., Babin, B. J., \& Anderson, R. E. (2010). Multivariate data analysis: A global perspective: Pearson Education.

Hamelin, N. D., Nikolis, A., Armano, J., Harris, P. G., \& Brutus, J. P. (2012). Evaluation of factors influencing confidence and trust in the patient-physician relationship: A survey of patient in a hand clinic. Chirurgie de la Main, 31(2), 83-90. https://doi.org/10.1016/i.main.2012.01.005

Hanson, D., \& Grimmer, M. (2007). The mix of qualitative and quantitative research in major marketing journals, 1993 2002. European journal of marketing, 41(1/2), 58-70. https://doi.org/10.1108/03090560710718111 
IPA. (2017). What is a public accountant? Retrieved from www.publicaccountants.org.au Jay, L., \& Schaper, M. (2003). Which advisors do micro-firms use? Some Australian evidence. Journal of Small Business and Enterprise Development, 10(2), 136-143. https://doi.org/10.1108/14626000310473166

Khadem, N. (2012). Accounting 100: The fight for the top. Retrieved from www.brw.com.au website:

Kirby, D. A., \& King, S. H. (1997). Accountants and small firm development: Filling the expectation gap. The Service Industries Journal, 17(2), 294-304.

Kotler, P., \& Keller, K. L. (2012). Marketing management (14 ed.). Essex: Pearson Education Limited.

Leung, P., Raar, J., \& Tangey, G. (2008). Accounting services and SMEs: An Australian study (C. A. E. T. (London) Ed.): The Association of Chartered Certified Accountants.

Lian, P. C., \& Laing, A. W. (2007). Relationships in the purchasing of business to business professional services: The role of personal relationships. Industrial Marketing Management, 36(6), 709-718. https://doi.org/10.1016/j.indmarman.2006.05.004

Neu, D. (1991). Trust, impression management and the public accounting profession. Critical Perspectives on Accounting, 2(3), 295-313. https://doi.org/10.1016/1045-2354(91)90015-6

Nilsson, M., \& Mattes, J. (2015). The spatiality of trust: Factors influencing the creation of trust and the role of face-to-face contacts. European Management Journal, 33(4), 230-244. https://doi.org/10.1016/j.emj.2015.01.002

Noroozi, A., \& Addison, G. (2008). [Submission on the discussion paper by the Australian Taxation Office on outsourcing and offshoring].

Pesämaa, O., Pieper, T., Vinhas da Silva, R., Black, W. C., \& Hair Jr, J. F. (2013). Trust and reciprocity in building inter-personal and inter-organizational commitment in small business co-operatives. Journal of Co-operative Organization and Management, 1(2), 8192. https://doi.org/10.1016/j.jcom.2013.10.003

Sarantakos, S. (2005). Varieties of social research. In social research (3 ed.). Basingstoke, England: Palgrave Macmillan.

Saunders, C., Wu, Y. A., Li, Y., \& Weisfeld, S. (2004). Interorganizational trust in B2B relationships. Paper presented at the Proceedings of the 6th international conference on Electronic commerce. https://doi.org/10.1145/1052220.1052255

Sharif, K. J., Kalafatis, S. P., \& Samouel, P. (2005). Cognitive and behavioural determinants of trust in small and medium-sized enterprises. Journal of Small Business and Enterprise Development, 12(3), 409-421. https://doi.org/10.1108/14626000510612312

Sturgis, P., \& Smith, P. (2010). Assessing the Validity of Generalized Trust Questions: What Kind of Trust are we Measuring? International Journal of Public Opinion Research, 22(1), 74-92. https://doi.org/10.1093/ijpor/edq003

Theron, E., Terblanche, N. S., \& Boshoff, C. (2008). The antecedents of relationship commitment in the management of relationships in business-to-business (B2B) financial services. Journal of Marketing Management, 24(9-10), 997-1010. https://doi.org/10.1362/026725708X382019

Windle, P. (2017). Accounting Services in Australia. Retrieved from Australia: 
AABFJ | Volume 12, no. 1, 2018

\section{Appendix - Measurement Table:}

\begin{tabular}{|c|c|c|}
\hline Measurement & Survey Question & References/Sources \\
\hline \multicolumn{3}{|l|}{ Dependent Variable: } \\
\hline \multirow[t]{11}{*}{ Trust } & $\begin{array}{l}\text { I have confidence in my public } \\
\text { accountant's ability to provide } \\
\text { financial services to my } \\
\text { business. }\end{array}$ & $\begin{array}{l}\text { Adapted from Dyer and Chu (2011), Coulter } \\
\text { and Coulter (2002), Kirby and King (1997), } \\
\text { Bennett and Robson (2005), Blackburn et al. } \\
(2010,2014)\end{array}$ \\
\hline & $\begin{array}{l}\text { My public accountant takes a } \\
\text { proactive approach in relation } \\
\text { to suggesting improvements } \\
\text { for my business. }\end{array}$ & Adapted from Blackburn et al. $(2010,2014)$ \\
\hline & $\begin{array}{l}\text { My public accountant always } \\
\text { acts in the best interests of my } \\
\text { business. }\end{array}$ & $\begin{array}{l}\text { Adapted from Hamelin, Nikolis, Armano, } \\
\text { Harris, and Brutus (2012), Dyer and Chu } \\
\text { (2011), Chumpitaz Caceres and Paparoidamis } \\
\text { (2007), Pesämaa, Pieper, Vinhas da Silva, } \\
\text { Black, and Hair Jr (2013) }\end{array}$ \\
\hline & $\begin{array}{l}\text { I have full trust in my public } \\
\text { accountant's ability to provide } \\
\text { financial services to my } \\
\text { business. }\end{array}$ & $\begin{array}{l}\text { Adapted from Berry et al. (2006), Chumpitaz } \\
\text { Caceres and Paparoidamis (2007) }\end{array}$ \\
\hline & $\begin{array}{l}\text { My public accountant is } \\
\text { sincere in their dealing with } \\
\text { my business. }\end{array}$ & Adapted from Dyer and Chu (2011), \\
\hline & $\begin{array}{l}\text { My public accountant is } \\
\text { trustworthy. }\end{array}$ & $\begin{array}{l}\text { Adapted from Coulter and Coulter (2002), } \\
\text { Bennett and Robson (2005) }\end{array}$ \\
\hline & $\begin{array}{l}\text { My public accountant puts my } \\
\text { business's interests above their } \\
\text { own. }\end{array}$ & $\begin{array}{l}\text { Adapted from Blois (1999), Chumpitaz Caceres } \\
\text { and Paparoidamis (2007) }\end{array}$ \\
\hline & $\begin{array}{l}\text { My public accountant is a } \\
\text { trusted advisor to my business. }\end{array}$ & $\begin{array}{l}\text { Adapted from Sturgis and Smith (2010), } \\
\text { Bennett and Robson (2005) }\end{array}$ \\
\hline & $\begin{array}{l}\text { My public accountant is my } \\
\text { MOST trusted business } \\
\text { advisor. }\end{array}$ & Adapted from Berry et al. (2006) \\
\hline & $\begin{array}{l}\text { My public accountant can be } \\
\text { relied upon to fulfil their } \\
\text { commitments /promises. }\end{array}$ & $\begin{array}{l}\text { Adapted from Blackburn et al. (2010, 2014), } \\
\text { Leung et al. (2008), Chumpitaz Caceres and } \\
\text { Paparoidamis (2007) }\end{array}$ \\
\hline & $\begin{array}{l}\text { I am happy to refer my public } \\
\text { accountant to other business } \\
\text { acquaintances. }\end{array}$ & $\begin{array}{l}\text { Adapted from Blackburn et al. }(2010,2014) \text {, } \\
\text { Leung et al. (2008) }\end{array}$ \\
\hline \multicolumn{3}{|l|}{ Independent Variables: } \\
\hline Length of Relationship $\left(\mathrm{H}_{1}\right)$ & $\begin{array}{l}\text { How many years has your } \\
\text { business been dealing with } \\
\text { your current public accountant } \\
\text { firm? }\end{array}$ & $\begin{array}{l}\text { Adapted from Dyer and Chu (2011), Coulter } \\
\text { and Coulter (2002), Dyer and Ross (2007), } \\
\text { Blackburn et al. (2010, 2014) }\end{array}$ \\
\hline Face-to-Face Contact $\left(\mathbf{H}_{2}\right)$ & $\begin{array}{l}\text { My main contact with my } \\
\text { public accountant is face-to- } \\
\text { face. }\end{array}$ & $\begin{array}{l}\text { Adapted from Dyer and Chu (2011), Nilsson } \\
\text { and Mattes (2015) }\end{array}$ \\
\hline
\end{tabular}


Cherry, McGrath \& Baumann | Client Intimacy \& Performance Advice

\begin{tabular}{|c|c|c|}
\hline & $\begin{array}{l}\text { My main contact with my } \\
\text { public accountant is via email. }\end{array}$ & Adapted from Nilsson and Mattes (2015) \\
\hline & $\begin{array}{l}\text { My main contact with my } \\
\text { public accountant is over the } \\
\text { phone. }\end{array}$ & Adapted from Nilsson and Mattes (2015) \\
\hline & $\begin{array}{l}\text { Face-to-face contact with my } \\
\text { public accountant is important } \\
\text { to me. }\end{array}$ & $\begin{array}{l}\text { Adapted from Dyer and Chu (2011), Nilsson } \\
\text { and Mattes (2015) }\end{array}$ \\
\hline & $\begin{array}{l}\text { I am satisfied with the level of } \\
\text { face-to-face contact provided } \\
\text { by my public accountant. }\end{array}$ & Adapted from Nilsson and Mattes (2015) \\
\hline \multirow[t]{5}{*}{ Degree of Engagement $\left(\mathrm{H}_{3}\right)$} & $\begin{array}{l}\text { My primary relationship with } \\
\text { my public accountant is via a } \\
\text { Partner (Yes/No - choose one). }\end{array}$ & $\begin{array}{l}\text { Adapted from Lian and Laing (2007), Pesämaa } \\
\text { et al. (2013) }\end{array}$ \\
\hline & $\begin{array}{l}\text { My public accountant has a } \\
\text { good understanding of my } \\
\text { business. }\end{array}$ & $\begin{array}{l}\text { Adapted from Gooderham, Tobiassen, Døving, } \\
\text { and Nordhaug (2004), Leung et al. (2008), } \\
\text { Chumpitaz Caceres and Paparoidamis (2007) }\end{array}$ \\
\hline & $\begin{array}{l}\text { I enjoy a strong commercial } \\
\text { relationship with my public } \\
\text { accountant. }\end{array}$ & Adapted from Dyer and Ross (2007) \\
\hline & $\begin{array}{l}\text { I enjoy a strong personal } \\
\text { relationship with the principal } \\
\text { contact at my public } \\
\text { accountant, outside our } \\
\text { commercial relationship. }\end{array}$ & Adapted from Blackburn et al. $(2010,2014)$ \\
\hline & $\begin{array}{l}\text { Overall, I am happy with the } \\
\text { level of service provided by my } \\
\text { public accountant. }\end{array}$ & $\begin{array}{l}\text { Adapted from Chumpitaz Caceres and } \\
\text { Paparoidamis (2007) }\end{array}$ \\
\hline \multirow[t]{4}{*}{ Breadth of Assistance $\left(\mathrm{H}_{4}\right)$} & $\begin{array}{l}\text { My public accountant offers } \\
\text { tax compliance advice to my } \\
\text { business. }\end{array}$ & Adapted from Dyer and Chu (2011), \\
\hline & $\begin{array}{l}\text { I am confident in my public } \\
\text { accountant's ability to provide } \\
\text { effective tax compliance } \\
\text { advice. }\end{array}$ & $\begin{array}{l}\text { Adapted from Coulter and Coulter (2002), } \\
\text { Gooderham et al. (2004) }\end{array}$ \\
\hline & $\begin{array}{l}\text { My public accountant offers } \\
\text { other services, beyond tax } \\
\text { compliance advice, to my } \\
\text { business. }\end{array}$ & $\begin{array}{l}\text { Adapted from Dyer and Chu (2011), Kirby and } \\
\text { King (1997), Blackburn et al. }(2010,2014)\end{array}$ \\
\hline & $\begin{array}{l}\text { My public accountant's } \\
\text { primary role is to ensure that } \\
\text { my business taxes are } \\
\text { completed accurately and in a } \\
\text { timely fashion. }\end{array}$ & Adapted from Berry et al. (2006) \\
\hline \multirow[t]{3}{*}{$\begin{array}{lll}\text { Advisory } & \text { Services } & \text { Offered } \\
\left(\mathrm{H}_{5}\right) & \end{array}$} & $\begin{array}{l}\text { My public accountant offers } \\
\text { broader business advisory } \\
\text { services to my business. }\end{array}$ & $\begin{array}{l}\text { Adapted from Coulter and Coulter (2002), } \\
\text { Berry et al. (2006), Kirby and King (1997), } \\
\text { Berry et al. (2006) }\end{array}$ \\
\hline & $\begin{array}{l}\text { My public accountant helps me } \\
\text { improve the performance of my } \\
\text { business. }\end{array}$ & $\begin{array}{l}\text { Adapted from Coulter and Coulter (2002), } \\
\text { Berry et al. (2006) }\end{array}$ \\
\hline & $\begin{array}{l}\text { I am confident in my public } \\
\text { accountant's ability to provide } \\
\text { effective general business } \\
\text { advice. }\end{array}$ & Adapted from Coulter and Coulter (2002) \\
\hline
\end{tabular}


AABF J | Volume 12, no. 1, 2018

\begin{tabular}{|c|c|c|}
\hline & $\begin{array}{l}\text { My public accountant provides } \\
\text { advice on how to grow my } \\
\text { business. }\end{array}$ & Adapted from Kirby and King (1997) \\
\hline & $\begin{array}{l}\text { Access to broader business } \\
\text { advisory services is important } \\
\text { to my business. }\end{array}$ & Adapted from Blackburn et al. $(2010,2014)$ \\
\hline \multirow[t]{2}{*}{ Accreditation Body $\left(\mathrm{H}_{6}\right)$} & $\begin{array}{l}\text { My public accountant's } \\
\text { accreditation body is } \\
\text { important to me. }\end{array}$ & $\begin{array}{l}\text { Adapted from Coulter and Coulter (2002), } \\
\text { Berry et al. (2006), Neu (1991) }\end{array}$ \\
\hline & $\begin{array}{l}\text { My public accountant is } \\
\text { accredited to (choose one). }\end{array}$ & Adapted from Blackburn et al. $(2010,2014)$ \\
\hline \multirow[t]{2}{*}{ Size $\left(\mathrm{H}_{7}\right)$} & $\begin{array}{ll}\text { My public accountant has } \\
\\
\text { Partners (choose one). }\end{array}$ & $\begin{array}{l}\text { Adapted from Gooderham et al. (2004), } \\
\text { Bennett and Robson (2005) }\end{array}$ \\
\hline & $\begin{array}{cl}\text { My } & \text { public accountant has } \\
& \text { office(s) (choose one). }\end{array}$ & $\begin{array}{l}\text { Adapted from Gooderham et al. (2004), } \\
\text { Bennett and Robson (2005) }\end{array}$ \\
\hline
\end{tabular}

